\title{
Dampak nyata pengabdian perguruan tinggi dalam membangun negeri
}

\author{
Almasdi Syahza \\ Ketua Lembaga Penelitian dan Pengabdian kepada Masyarakat, Universitas Riau \\ * almasdi.syahza@ lecturer.unri.ac.id
}

Iptek dan pendidikan tinggi dapat berkontribusi dalam penguatan perekonomian dan peningkatan kesejahteraan masyarakat. Hal ini ditunjukkan oleh keunggulan teknologi yang dihasilkan maupun kemitraan dengan dunia industri. Perguruan tinggi di Indonesia telah menghasilkan inovasi yang mendatangkan manfaat langsung bagi masyarakat. Kegiatan pengabdian kepada masyarakat merupakan bentuk keterlibatan perguruan tinggi mengimplementasi pengetahuan. Perguruan tinggi harus meyakinkan cara berpikir akademisi bahwa Tri Dharma perguruan tinggi merupakan satu paket kegiatan dan simbol keberhasilan suatu institusi sebagai perguruan tinggi. Pengabdian mampu memberdayakan masyarakat dengan penerapan teknologi tepat guna, implementasi model pemecahan masalah, dan rekayasa sosial. Pengabdian perguruan tinggi dapat menghasilkan hak kekayaan intelektual dan juga rekomendasi kebijakan yang dapat diterapkan langsung oleh masyarakat, dunia usaha, industri, dan pemerintah.

Kata kunci: pengabdian kepada masyarakat; perguruan tinggi; tri dharma; iptek; dampak

\begin{abstract}
Human resources produced by universities must be involved in increasing the nation's competitiveness. Science and technology and higher education can contribute to strengthening the economy and improving people's welfare. It is shown by the technology advantage produced and partnerships with the industrial sector. Higher education institutions in Indonesia have produced innovations that bring direct benefits to the community. Community service activities are a form of university involvement in implementing knowledge. Higher education must convince academics to think that the Tri Dharma of higher education is a package of activities and a symbol of the success of an institution as a college. Community service can empower people by applying appropriate technology, problem-solving models, and social design. Community services of higher education can produce intellectual property rights and also policy recommendations that can be applied by the community, business, industry, and government.
\end{abstract}

Keywords: community service; university; tri dharma; science and technology; impact

To cite this article: Syahza, A. 2019. Dampak Nyata Pengabdian Perguruan Tinggi dalam Membangun Negeri. Unri Conference Series: Community Engagement 1: 1-7. https://doi.org/10.31258/unricsce.1.1-7

(C) 2019 Author

Peer-review under responsibility of the organizing committee of Seminar Nasional Pemberdayaan Masyarakat 2019 


\section{PENDAHULUAN}

Dalam Undang-undang Nomor 14 Tahun 2005 tentang Guru dan Dosen pasal 60, dosen dalam melaksanakan tugas keprofesionalan berkewajiban, antara lain: a) Melaksanakan pendidikan, penelitian, dan pengabdian kepada masyarakat; b) Merencanakan, melaksanakan proses pembelajaran, serta menilai dan mengevaluasi hasil pembelajaran; c) Meningkatkan dan mengembangkan kualifikasi akademik dan kompetensi secara berkelanjutan sejalan dengan perkembangan ilmu pengetahuan, teknologi, dan seni; d) Bertindak objektif dan tidak diskriminatif atas dasar pertimbangan jenis kelamin, agama, suku, ras, kondisi fisik tertentu, atau latar belakang sosioekonomi peserta didik dalam pembelajaran; e) Menjunjung tinggi peraturan perundangundangan, hukum, dan kode etik, serta nilai-nilai agama dan etika; dan f) Memelihara dan memupuk persatuan dan kesatuan bangsa.

Pada pasal 72 ayat 1, beban kerja dosen mencakup kegiatan pokok yaitu merencanakan pembelajaran, melaksanakan proses pembelajaran, melakukan evaluasi pembelajaran, membimbing dan melatih, melakukan penelitian, melakukan tugas tambahan, serta melakukan pengabdian kepada masyarakat. Undang-undang Nomor 12 Tahun 2012 tentang Pendidikan Tinggi Pasal 45 menegaskan bahwa penelitian di perguruan tinggi diarahkan untuk mengembangkan ilmu pengetahuan dan teknologi, serta meningkatkan kesejahteraan masyarakat dan daya saing bangsa. Dalam pasal tersebut juga ditegaskan bahwa pengabdian kepada masyarakat merupakan kegiatan sivitas akademika dalam mengamalkan dan membudayakan ilmu pengetahuan dan teknologi untuk memajukan kesejahteraan umum dan mencerdaskan kehidupan bangsa.

Peran perguruan tinggi seharusnya memberikan kontribusi dalam pengembangan ilmu pengetahuan dan teknologi (Iptek) untuk kemajuan bangsa. Sumberdaya manusia (SDM) yang dihasilkan Perguruan Tinggi (PT) harus terlihat pada peningkatan daya saing bangsa. Iptek dan pendidikan tinggi dapat memberikan kontribusi dalam penguatan perekonomian, peningkatan kesejahteraan masyarakat yang ditunjukkan oleh keunggulan produk teknologi yang dihasilkan oleh PT maupun yang bermitra dengan dunia industri/perusahaan. Seperti diketahui, PT Indonesia telah banyak menghasilkan inovasi yang mendatangkan manfaat langsung bagi masyarakat.

\section{TUGAS DAN TANGGUNG JAWAB DOSEN SEBAGAI PELAKSANA TRI DHARMA PERGURUAN TINGGI}

Dalam upaya menumbuh-kembangkan jatidiri perguruan tinggi, tentu saja peran dan tugas pelaksana tri dharma PT harus mampu membawa institusinya menjadi PT yang dibanggakan baik secara nasional maupun internasional. Salah satunya adalah tugas dan peran dosen. Dosen merupakan pendidik profesional dan ilmuwan dengan tugas utama mentransformasikan, mengembangkan, dan menyebarluaskan ilmu pengetahuan, teknologi, dan seni melalui pendidikan, penelitian, dan pengabdian kepada masyarakat. Dosen sebagai kebanggaan perguruan tinggi memiliki tugas mengajar dan membimbing mahasiswa agar yang bersangkutan memiliki kompetensi yang relevan dengan keahliannya serta memiliki tanggung jawab pengembangan ilmu pengetahuan melalui penelitian yang semestinya dilakukan secara terus menerus. Artinya seorang dosen tidak pernah berhenti melalukan penelitian sesuai dengan bidang keahliannya. Hasil dari penelitian tersebut dapat dimanfaatkan oleh masyarakat dalam bentuk inovasi, atau berupa teknologi tepat guna. Pemanfaatan hasil riset bisa saja dilakukan melalui perkenalan produk baru yang bernilai ekonomi yang bermitra dengan dunia usaha. Dari sisi lain bisa saja dalam bentuk penerapan Teknologi Tepat Guna (TTG) (Fitmawati et al., 2018; Rusliadi et al., 2018), bahan/buku ajar yang dipakai oleh dosen untuk pengkayaan materi ajar di kelas. Hasil riset seharusnya memunculkan materi-materi ajar yang terbarukan dan disesuaikan dengan kebutuhan masyarakat. Hasil riset tersebut akan memberikan nilai tambah dan kontribusi ekonomi secara nasional.

Dosen merupakan ujung tombak perguruan tinggi dalam pelaksanaan tri dharma-nya. Dosen seharusnya membawa perguruan tingginya ke dunia luar kampus dari hasil riset dan pengabdian kepada maasyarakat. Keberhasilan dosen dalam riset maupun pengabdian merupakan kebanggaan PT tempat dia mengabdi. Untuk itu tugas dosen harus mampu mendukung visi dan misi PT. Sejalan untuk memperkenalkan hasil Iptek ke masyarakat, maka tugas dosen, antara lain: 1) mampu menciptakan suasana atau iklim proses pembelajaran yang dapat memotivasi; 2) memiliki tugas yang beragam yang berimplementasi dalam bentuk pengabdian berupa bidang profesi, bidang kemanusiaan, dan bidang kemasyarakatan; 3) mampu mengimplementasikan ilmu sebagai profesi meliputi mendidik, mengajar dan melatih; 4) mampu mengembangkan ilmu pengetahuan dan teknologi melalui proses pembelajaran dan pengabdian; 5) mampu merencanakan dan melaksanakan pengajaran baik dikelas maupun di masyarakat; 6) mampu melaksanakan pendidikan, penelitian, dan pengabdian kepada masyarakat; 7) mampu merencanakan, melaksanakan proses pembelajaran, serta menilai 
dan mengevaluasi hasil pembelajaran; dan 8) mampu meningkatkan dan mengembangkan kualifikasi akademik dan kompetensi secara berkelanjutan sejalan dengan perkembangan ilmu pengetahuan, teknologi, dan seni.

\section{KEAHLIAN YANG DIBUTUHKAN SEORANG DOSEN UNTUK PENGABDIAN}

Dosen merupakan tenaga pendidik sekaligus sebagai agen pembelajaran. Dosen dalam pengembangan profesi sebagai ilmuan juga mengembangkan kemampuaan ditengah masyarakat melalui kegiatan pengabdian. Karena itu aktivitas dosen merupakan sebuah profesi dan bakat. Tidak mudah untuk menjadi seorang pengajar (dosen) yang profesional tanpa diikuti oleh bakat pendidik. Supaya bakat pendidik dan pengkayaan ilmu pengetahuan dapat disampaikan kepada peserta didik maupun masyarakat maka seorang dosen harus melaksanakan tri dharma PT. Keahlian diperoleh jika sering melakukan penelitian dan mengimplementasikan dalam kehidupan bermasyarakat (Syahza, 2017). Maka di PT setiap dosen wajib melaksanakan tri dharma dalam upaya pengembangan ilmu pengetahuan dan penyampaiannya ke masyarakat. Salah satu bentuk kegiatan implementasi pengetahuan adalah pengabdian kepada masyarakat.

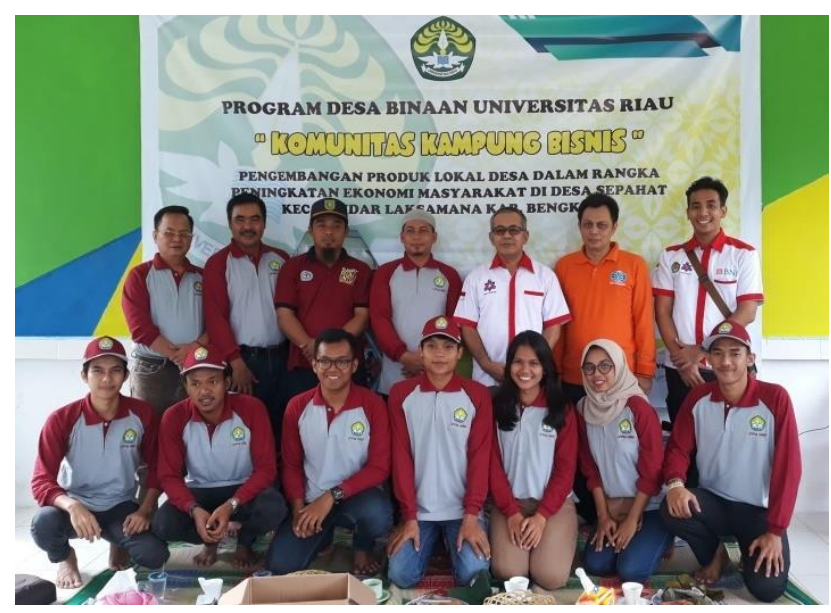

Gambar 1. Tim Pengabdian Kepada Masyarakat Universitas Riau bersama Mahasiswa KKN Membangun Kampung Bisnis (Syahza, 2018)

Pengabdian kepada masyarakat adalah salah satu kewajiban dosen untuk berkontribusi untuk bangsa. Kegiatan penelitian dan pengabdian kepada masyarakat merupakan elemen dari Tri Dharma Perguruan Tinggi (DRPM Kemenristekdikti, 2018). Kedua elemen tersebut menjadi aksi dari keterlibatan perguruan tinggi dalam pembangunan dan menghilangkan isolasi dunia akademik terhadap persoalan masyarakat. Sebagian dosen kegiatan pengabdian kepada masyarakat masih dijadikan sebagai pekerjaan sampingan dan tidak menarik. Dosen masih terfokus kepada proses belajar-mengajar. Padahal pengabdian merupakan ciri khas jatidiri perguruan tinggi dalam upaya menyebarkan ilmu pengetahuan kepada masyarakat. Sering ditemukan bahwa kegiatan penelitian dan pengabdian kepada masyarakat masih digunakan sebagai ajang perolehan cumulative credit point dalam rangka menaikkan pangkatnya.

Perguruan Tinggi harus mampu meyakinkan cara berpikir dosen bahwa Tri Dharma PT merupakan satu paket kegiatan dan simbol keberhasilan suatu institusi sebagai perguruan tinggi. Karena itu penelitian, dan pengabdian terhadap masyarakat diharapkan menjadi kegiatan berkesinambungan untuk membantu masyarakat dalam menangani permasalahan yang mereka hadapi. Terlebih jika luaran kedua kegiatan tersebut jelas dan bermanfaat terhadap kemajuan masyarakat. Peningkatan kegiatan pengabdian kepada masyarakat masih perlu ditingkatkan, sebab dukungan penuh dari Kemenristekdikti melalui DRPM memberikan kesempatan kepada para peneliti, khususnya di kalangan dosen untuk mengimplementasikan hasil risetnya dalam bentuk pengabdian.

\section{PENGABDIAN KEPADA MASYARAKAT SEBAGAI JATIDIRI PERGURUAN TINGGI}

Pengabdian kepada masyarakat seharusnya merupakan hilirisasi dari penelitian. Hasil penelitian baik bersifat sain dan teknologi (khususnya teknologi tepat guna) maupun kajian sosial dan ekonomi. Pengabdian 
merupakan salah satu cerminan keberhasilan pelaksanaan tri dharma bagi perguruan tinggi. Sehingga kegiatan pengabdian yang bersifat inovatif, berdaya saing serta mampu memberikan identitas bela negara dapat memberikan ciri jatidiri Perguruan Tinggi bersangkutan.

Kegiatan pengabdian juga dapat menggambarkan secara kuantitatif potret, profil dan kondisi khalayak sasaran yang akan dilibatkan dalam kegiatan pengabdian kepada masyarakat. Kondisi dan potensi wilayah dari segi fisik, sosial, ekonomi maupun lingkungan yang relevan dengan kegiatan yang akan dilakukan. Pengabdian yang dilakukan harus berbasis penelitian (baik penelitian sendiri maupun hasil riset orang lain).

Seorang dosen atau tim pengabdian mampu mengidentifikasi permasalahan dan potensi sumberdaya yang ada di daerah sasaran untuk dijadikan sebagai sumber ide kegiatan pengabdian. Informasi potensi yang dapat dijadikan sebagai bahan kegiatan pengabdian kepada masyarakat. Dalam pelaksana kegiatan pengabdian dapat mengungkapkan masalah secara konkrit dan jelas. Sebelum kegiatan pengabdian dilaksanakan harus mampu melakukan perumusan masalah dan menjelaskan pula definisi, asumsi dan lingkup yang menjadi batasan kegiatan pengabdian kepada masyarakat.

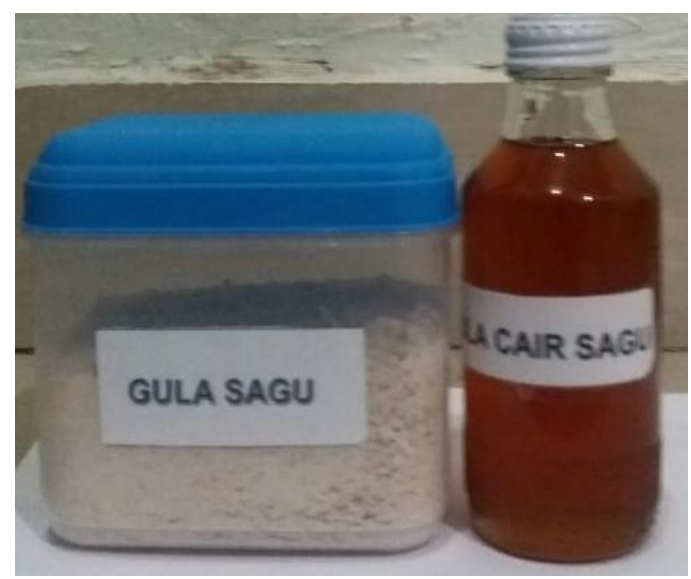

Gambar 2. Salah Satu Bentuk Hasil Pengabdian Pembuatan Gula berbasis Sagu oleh Tim Pengabdian Universitas Riau

Aktivitas kegiatan pengabdian bagi khalayak sasaran, dari sisi ekonomi maupun pengembangan ilmu pengetahuan harus terlihat jelas dan dapat diukur. Jika dalam bentuk penerapan TTG perlu dijelaskan kegunaannya dan nilai tambah yang diharapkan. Apabila dalam bentuk kebijakan perlu dijelaskan perubahan yang diharapkan setelah kegiatan tersebut. Pengabdian kepada masyarakat merupakan penyebaran ilmu pengetahuan, teknologi dan seni yang dapat dimanfaatkan secara langsung oleh masyarakat.

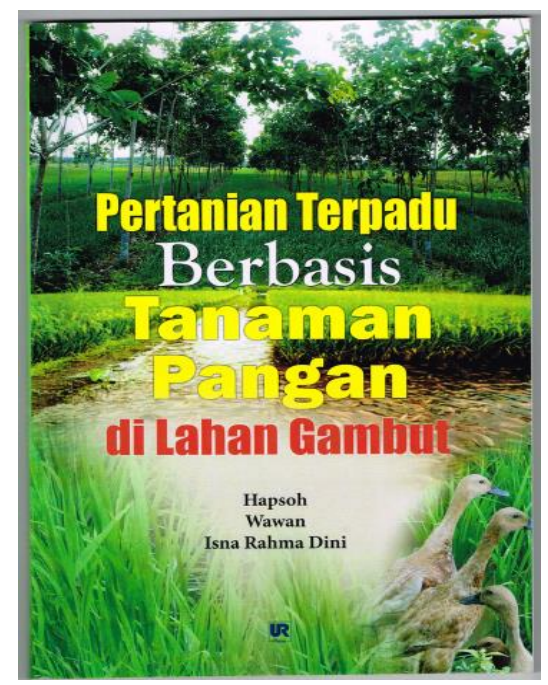

Gambar 3. Buku Teknologi Tepat Guna dari Hasil Pengabdian Dosen Fakultas Pertanian Universitas Riau 
Kegiatan Pengabdian kepada Masyarakat merupakan salah satu bentuk keterlibatan tim baik dari dosen maupun dari mahasiswa di perguruan tinggi untuk tujuan transformasi pengetahuan. Sering kegiatan pengabdian pada masyarakat lebih cendererung mengacu kepada visi perguruan tinggi. Setiap perguruan tinggi mempunyai visi dan ciri tersendiri, karena itu kegiatan pengabdian lebih ditekankan untuk mengembangkan pengetahuan dalam masyarakat yang terkait dengan ciri khas perguruan tinggi tersebut. Yang pada hakekatnya bertujuan untuk membangun desa atau suatu wilayah di pedesaan yang mandiri. Berbagai aktifitas kegiatan pengabdian perguruan tinggi yang sering dilakukan antara lain:

Adaptasi dan penerapan TTG berbasis Iptek, yakni kegiatan pengabdian kepada masyarakat dalam bentuk pengembangan dan penerapan hasil penelitian (action research) ataupun teknologi sederhana untuk mengembangkan potensi dan peluang yang terdapat pada suatu komunitas masyarakat (Riduwan, 2016). Tujuan kegiatan tersebut adalah mencapai tingkat efisiensi penggunaan sarana produksi atau nilai manfaat dari teknologi yang dapat menciptakan nilai tambah dan perubahan sikap perilaku dalam masyarakat.

Pemberdayaan ekonomi, yakni kegiatan pengabdian kepada masyarakat dalam rangka peningkatan kesejahteraan dan pendapatan (Syahza, 2016). Tujuan kegiatan memberikan pemahaman maupun cara pemanfaatan sumberdaya yang berpotensi dan punya nilai ekonomi (Irianti dkk, 2018; Syahrul et al., 2018; Soverda et al., 2018). Kegiatan dapat dilakukan melalui pemberdayaan peluang usaha dari potensi yang ada. Bisa saja berupa aktivitas penyuluhan dan peningkatan keterampilan usaha dari yang sudah ada dilakukan oleh masyarakat.

Pendampingan Masyarakat, yakni kegiatan pengabdian kepada masyarakat yang dilakukan secara intensif dan partisipatif agar tercapai kemandirian dari komunitas atau kelompok mitra, hal ini yang pernah dilakukan Evelyn et al. (2018), Herlina et al. (2018), Syahza et al. (2018), dan Suwarno et al. (2018). Kegiatan pendampingan bertujuan untuk meningkatkan daya saing berusaha sehingga kelompok masyarakat tersebut bisa menjadi mandiri (Riadi, 2017). Pendamping desa mempunyai fungsi penting dalam meningkatkan peran serta masyarakat dan kelembagaan di pedesaan dalam kegiatan pembangunan. Partisipasi masyarakat dapat dianggap sebagai tolok ukur dalam menilai kegiatan di pedesaan (Syahza, 2015). Dari sisi lain juga dapat dilakukan dalam bentuk pembelajaran masyarakat, advokasi, dan layanan masyarakat.

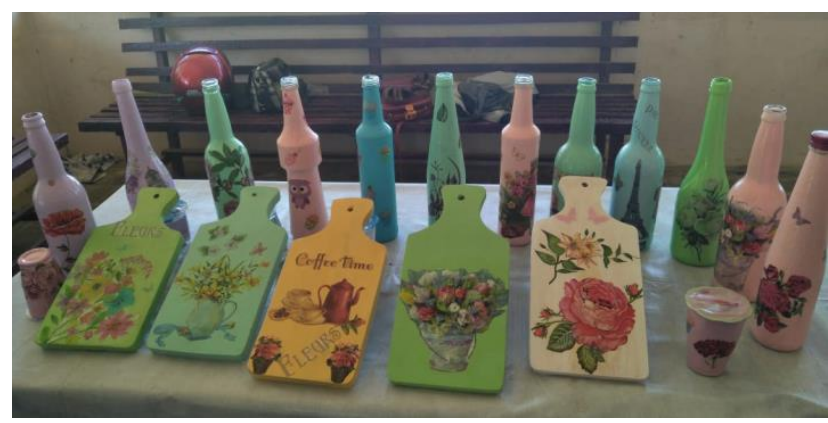

Gambar 4. Hasil Pelatihan Pemanfaatan Botol Bekas yang Bernilai Ekonomi oleh Tim Pengabdian Universitas Riau

Dosen sebagai pelaksana tri dharma di perguruan tinggi harus mampu memberikan kontribusi ke institusi dimana tempat dia mengabdi. Kotribusi tersebut dari hasil penelitian dan hilirisasi penelitian yang di aplikasikan dalam kegiatan pengabdian kepada masyarakat. Hasil penelitian tersebut mampu mengangkat marwah perguruan tingginya. Dalam kegiatan pengabdian diharapkan dosen mampu juga memberikan kontribusi pengabdian di daerah belupa penerapan sain dan teknologi baik dilakukan secara langsung maupun melalui program kuliah kerja nyata $(\mathrm{KKN})$ mahasiswa. Sehingga kegiatan pengabdian merupakan kebanggan bagi perguruan tinggi pelaksana. Kegiatan yang dilakukan dapat berupa menerapkan, mengamalkan, dan membudayakan ilmu pengetahuan dan teknologi guna memajukan kesejahteraan masyarakat khususnya di pedesaan. Dalam jangka panjang akan mampu mencerdaskan kehidupan bangsa. Setelah kegiatan pengabdian dilaksanakan, hasil kegiatan tersebut dapat menyelesaian masalah yang dihadapi masyarakat dengan memanfaatkan keahlian sivitas akademik yang relevan, pemanfaatan teknologi tepat guna, sebagai bahan pengembangan ilmu pengetahuan, dan teknologi atau bahan/buku ajar dalam bentuk modul pelatihan untuk pengayaan sumber belajar. 


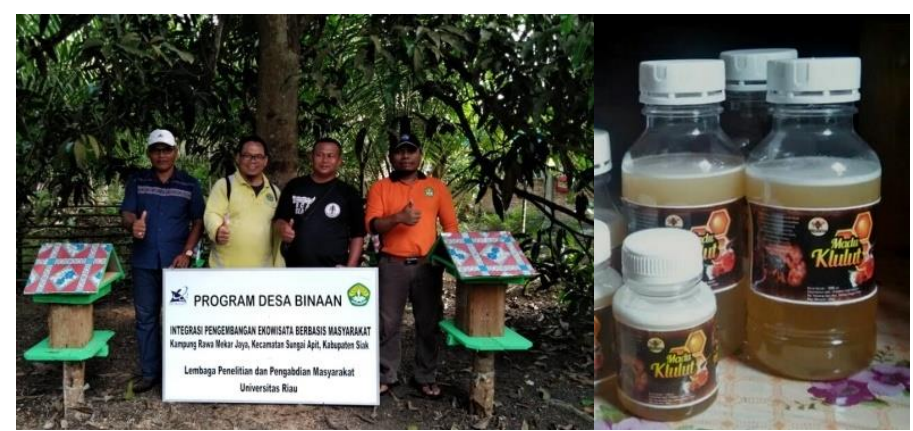

Gambar 5. Pembuatan Demplot Penangkaran Lebah Kelulut dan Pengayaan Tanaman Pakan Kelulut oleh Tim Pengabdian Desa Binaan Universitas Riau

Pada kegiatan pengabdian yang harus menjadi bahan pertimbangan adalah dari sisi materi kegiatan. Baik dari sisi kedalaman dan keluasan materi pengabdian, atau pengembangan ilmu pengetahuan dan teknologi yang diterapkan langsung dan dibutuhkan oleh masyarakat pengguna. Pengabdian mampu memberdayakan masyarakat dengan penerapan teknologi tepat guna yang dapat dimanfaatkan dalam rangka meningkatkan taraf hidup dan kesejahteraan masyarakat, model pemecahan masalah, rekayasa sosial. Dapat juga berupa rekomendasi kebijakan yang dapat diterapkan langsung oleh masyarakat, dunia usaha, industri, dan/atau pemerintah, serta hak kekayaan intelektual (HKI).

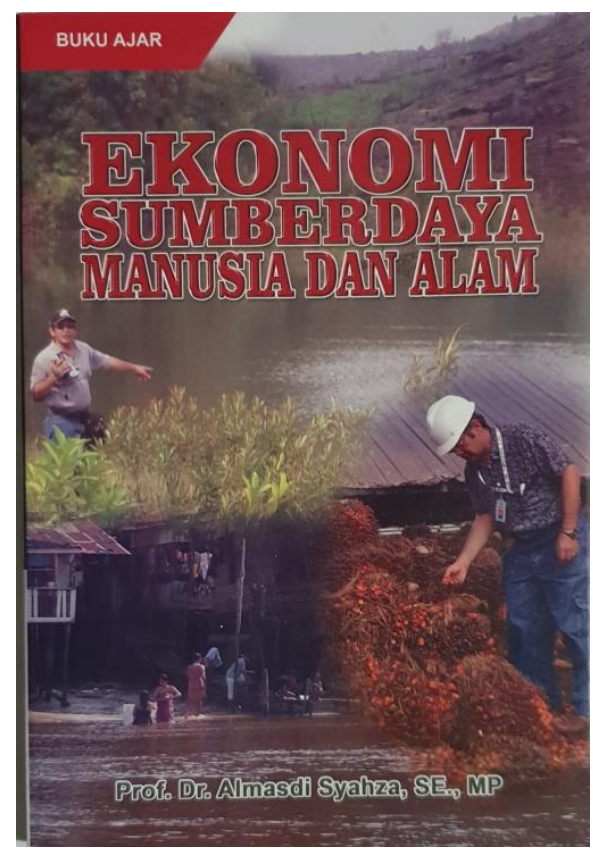

Gambar 6. Salah Satu Bentuk Buku Ajar Hasil Penelitian dan Pengabdian kepada Masyarakat

Dalam upaya menjaga jatidiri perguruan tinggi, maka proses pengabdian kepada masyarakat perlu juga menjadi perhatian bagi dosen pelaksana, antara lain: 1) kegiatan pengabdian kepada masyarakat menganut langkah-langkah perencanaan, pelaksanaan, dan pelaporan kegiatan; 2) kegiatan dapat berupa pelayanan kepada masyarakat, penerapan ilmu pengetahuan dan teknologi sesuai dengan bidang keahliannya, peningkatan kapasitas masyarakat, atau pemberdayaan masyarakat; 3) wajib mempertimbangkan standar mutu, menjamin keselamatan kerja, kesehatan, kenyamanan, serta keamanan pelaksana, masyarakat, dan lingkungan; 4) khusus kegiatan yang dilakukan oleh mahasiswa sebagai salah satu dari bentuk pembelajaran harus mengarah pada terpenuhinya capaian pembelajaran lulusan serta memenuhi ketentuan dan peraturan di perguruan tinggi; dan 5) harus diselenggarakan secara terarah, terukur, dan terprogram. 


\section{DAFTAR PUSTAKA}

DRPM Kemenristekdikti. 2018. Panduan Penelitian dan Pengabdian Kepada Masyarakat Edisi XII. Jakarta: Direktorat Riset dan Pengabdian Masyarakat Kemerintekdikti.

Evelyn, E. Saputra, Komalasari, \& S. Utami. 2018. Community training in dishwashing-liquid soap making from waste cooking oil. Riau Journal of Empowerment 1(2): 67-74. https://doi.org/10.31258/raje.1.2.9

Fitmawati, Isnaini, S. Fatonah, N. Sofiyanti, \& R. M. Roza. 2018. Penerapan teknologi hidroponik sistem deep flow technique sebagai usaha peningkatan pendapatan petani di Desa Sungai Bawang. Riau Journal of Empowerment 1(1): 23-29. https://doi.org/10.31258/raje.1.1.3

Herlina, S., W. Winarti, \& C. Wahyudi. 2018. Meningkatkan pengetahuan dan kemampuan kader kesehatan melalui pelatihan bantuan hidup dasar. Riau Journal of Empowerment 1(2): 85-90. https://doi.org/10.31258/raje.1.2.11

Irianti, M., A. Syahza, B. Asmit, Suarman, RM Riadi, D. Bakce, \& D. Tampubulon. 2018. Peningkatan Pendapatan Masyarakat melalui Pemanfaatan Limbah Lidi Kelapa Sawit di Desa Sepahat Kabupaten Bengkalis. Paper presented at Seminar Nasional Hasil Pengabdian Kepada Masyarakat. https://conference.upnvj.ac.id/index.php/pkm/article/view/15

Riadi, M. 2017. Tujuan, Prinsip dan Tahapan Pemberdayaan Masyarakat. https://www.kajianpustaka.com/2017/11/tujuan-prinsip-dan-tahapan-pemberdayaan-masyarakat.html Diakses 20 Oktober 2018.

Riduwan, A. 2016. Pelaksanaan Kegiatan Pengabdian Kepada Masyarakat oleh Perguruan Tinggi. https://www.researchgate.net/publication/313778436, diakses 22 Oktober 2018.

Rusliadi, I. Putra, M. Fauzi, N. A. Pamukas, \& H. Masjudi. 2018. Pengembangan mata pencaharian alternatif bagi nelayan melalui kegiatan budidaya ikan dengan teknologi bioflok di Kampung Sungai Kayu Ara. Riau Journal of Empowerment 1(2): 61-65. https://doi.org/10.31258/raje.1.2.8

Soverda, N., Z. Alamsyah, E. Indraswari, Y. Alia, \& Neliyati. 2018. PPM Kelurahan Teratai Kecamatan Muara Bulian dalam upaya pemanfaatan lahan pekarangan untuk peningkatan produksi dan kualitas tanaman jahe merah. Riau Journal of Empowerment 1(1): 45-49. https://doi.org/10.31258/raje.1.1.6

Suwarno, E., Hadinoto, \& M. Ikhwan. 2018. Prioritas konservasi lahan dan arahan programnya di Kelurahan Minas Jaya Provinsi Riau. Riau Journal of Empowerment 1(1): 11-21. https://doi.org/10.31258/raje.1.1.2

Syahrul, Dewita, \& Restu. 2018. Implementasi pewarna alami untuk diversifikasi mie sagu ikan pada pelaku usaha mikro mie sagu di Kabupaten Kepulauan Meranti, Riau. Riau Journal of Empowerment 1(1): 31-36. https://doi.org/10.31258/raje.1.1.4

Syahza, A. 2015. Ekonomi Pembangunan Teori dan Kajian Empirik Pembangunan Pedesaan. Pekanbaru: Unripress.

Syahza, A. 2016. Ekonomi Sumberdaya Manusia dan Alam. Pekanbaru: Unripress.

Syahza, A. 2017. Metodologi Penelitian. Pekanbaru: Unripress.

Syahza, A. 2018. Pengembangan Produk Unggulan Desa dalam Rangka Peningkatan Ekonomi Masyarakat di Desa Sepahat Kecamatan Bandar Laksamana Kabupaten Bengkalis. Pekanbaru: LPPM Universitas Riau.

Syahza, A., D. Bakce, \& B. Asmit. 2018. Increasing the awareness of palm oil plantation replanting through farmers training. Riau Journal of Empowerment 1(1): 1-9. https://doi.org/10.31258/raje.1.1.1 